\title{
Pengaruh Model Pembelajaran Kooperatif Tipe Jigsaw Berbantuan Media Powerpoint Terhadap Kompetensi Pengetahuan PPKn
}

\author{
Ni Putu Mia Puspitaํㅗ I. G. A. Agung Sri Asri, I Ketut Ardana \\ 1Jurusan Pendidikan Dasar, Universitas Pendidikan Ganesha, Singaraja, Indonesia \\ e-mail: putu.mia.puspita@undiksha.ac.id¹, igaagungsri.asri@undiksha.ac.id², ikerut.ardana@undiksha.ac.id³
}

\begin{abstract}
Abstrak
Penelitian ini bertujuan untuk mengetahui perbedaan yang signifikan kompetensi pengetahuan PPKn kelompok siswa yang dibelajarkan dengan model pembelajaran Kooperatif Tipe Jigsaw berbantuan media powerpoint dengan kelompok siswa dibelajarkan dengan pembelajaran konvensional pada kelas V SD Gugus III Kecamatan Kuta Utara Tahun Ajaran 2018/2019. Penelitian ini merupakan penelitian eksperimen semu dengan rancangan kelompok non-equivalen control grop desain. Populasi pada penelitian ini ialah seluruh siswa kelas V SD Gugus III Kecamatan Kuta Utara Tahun Ajaran 2018/2019 yang berjumlah 14 kelas terdiri atas 522 orang. Penentuan sampel dalam penelitian ini menggunakan teknik random sampling dengan pengacakan kelas yang sudah ada, kemudian dilakukan pengundian untuk penentuan kelompok eksperimen dan kontrol sehingga kelas V B SD 1 Kerobokan sebanyak 33 siswa sebagai kelompok kelas eksperimen dan kelas V B SD 2 Kerobokan Kaja sebanyak 30 siswa sebagai kelompok kelas kontrol. Data yang terkumpul dianalisis menggunakan analisis ststistik deskriptif dan statistic inferensial uji-t. Berdasarkan uji analisis data. Diperoleh $t_{\text {hitung }}=5,617$ dan tabel pada taraf signifikansi $5 \% \mathrm{dk}, 61=2,000$. Hal ini berarti thitung $>t_{\text {tabel }}$ sehingga dapat diinterprestasikan bahwa terdapat perbedaan yang signifikan kompetensi pengetahuan PPKn antara kelompok eksperimen dengan kelompok kontrol. Dilihat dari rata-rata kompetensi pengetahuan, kompetensi pengetahuan PPKn kelompok eksperimen adalah 0,218 lebih besar dari ratarata kompetensi pengetahuan PPKn kelas kontrol yaitu 0,097. Dengan demikian dapat disimpulkan pembelajaran Kooperatif Tipe Jigsaw berbantuan media powerpoint berpengaruh terhadap kompetensi pengetahuan PPKn siswa kelas V SD Gugus III Kecamatan Kuta Utara Tahun Ajaran 2018/2019.
\end{abstract}

Keywords:

Jigsaw, powerpoint, kompetensi pengetahuan PPKn

\section{Pendahuluan}

Pendidikan merupakan sarana utama dalam membentuk dan menciptakan sumber daya manusia yang berkualitas, baik melalui pendidikan informal maupun pendidikan formal. Menurut Hamalik (2014:3), "Pendidikan adalah suatu proses dalam rangka mempengaruhi peserta didik supaya mampu menyesuaikan diri sebaik mungkin dengan lingkungannya, dan dengan demikian akan menimbulkan perubahan dalam dirinya yang memungkinkan untuk berfungsi secara adekwat dalam kehidupan bermasyarakat". Pendidikan mengemban tugas untuk menghasilkan generasi yang baik. Sekolah sebagai lembaga formal merupakan sarana dalam rangka pencapaian tujuan pendidikan tersebut. Melalui sekolah, siswa belajar berbagai macam hal. Dalam pendidikan 
formal, belajar menunjukkan adanya perubahan yang sifatnya positif sehingga pada tahap akhir akan didapat keterampilan, kecakapan dan pengetahuan baru.

Perkembangan pendidikan di sekolah dasar sangatlah penting, karena pada jenjang sekolah dasar siswa ditanami pendidikan dasar yang akan berguna bagi siswa dikemudian hari, namun di sekolah dasar masih banyak kendala-kendala yang dihadapi guru dalam proses pembelajaran seperti, kurangnya perhatian siswa saat belajar, suka mengantuk di dalam kelas, mengobrol dengan sesama temannya dan lain sebagainya, hal tersebut muncul karena kurang optimalnya penggunaan model pembelajaran. Peranan model pembelajaran sangatlah penting untuk menunjang proses pembelajaran agar menjadi lebih menarik. Berhasil dan tidaknya suatu pendidikan juga sangat dipengaruhi oleh kurikulum yang ada.

Kurikulum saat ini menuntut perkembangan kualitas pendidikan yang lebih baik dan lebih maju. Seiring dengan perkembangan jaman dan teknologi yang sangat pesat, pemerintah melakukan perubahan kurikulum dengan tujuan untuk meningkatkan kualitas pendidikan. Di Indonesia, pengertian kurikulum terdapat pada pasal1 butir 19 UU Nomor 20 Tahun 2003 tentang Sistem Pendidikan Nasional, yaitu kurikulum adalah seperangkat rencana dan pengaturan mengenai tujuan, isi, dan bahan pelajaran serta cara yang digunakan melalui pedoman penyelenggaraan kegiatan pembelajaran untuk mencapai tujuan pendidikan tertentu. Berdasarkan pengertian kurikulum itu sendiri, maka bisa dikatakan bahwa kurikulum merupakan alat yang sangat penting bagi keberhasilan suatu pendidikan. Tanpa kurikulum yang sesuai dan tetap, maka suatu tujuan dan sasaran dari pendidikan akan sulit dicapai.

Dalam sejarah pendidikan di Indonesia sudah beberapa kali diadakan perubahan dan perbaikan kurikulum. Perubahan kurikulum tersebut didasari pada kesadaran bahwa perkembangan dan perubahan yang terjadi menuntut perlunya perbaikan sistem pendidikan nasional, termasuk penyempurnaan kurikulum untuk mewujudkan masyarakat yang mampu bersaing dan menyesuaikan diri dengan perubahan. Peraturan Permendikbud nomor 67 Tahun 2013 yang mengatur tentang kerangka dasar dan struktur kurikulum Sekolah Dasar/ Madrasah Ibtidaiyah, dimana melalui peraturan ini diberlakukannya kurikulum baru yaitu kurikulum 2013. Kurikulum 2013 merupakan kurikulum yang berbasis tematik teintegratif. Tujuan dari kurikulum 2013 adalah untuk meningkatkan rasa ingin tahu siswa dan mendorong siswa menjadi lebih aktif. Pada kurikulum ini siswa tidak lagi menjadi objek justru siswa menjadi subjek dengan ikut mengembangkan tema yang ada. Dengan adanya perubahan kurikulum tentunya berbagai strandar dan komponen pendidikan juga akan berubah, baik itu strandar isi, standar proses maupun standar kompetensi lulusan. Guru merupakan salah satu faktor yang dapat memperbaiki kualitas pendidikan. Peran guru sangatlah dibutuhkan untuk mendukung terciptanya suasana proses pembelajaran yang menyenangkan, aktif, kreatif, dan memungkinkan anak berprestasi secara optimal. Dalam proses pembelajaran guru perlu menyajikan pembelajaran yang menarik dan menyenangkan bagi peserta didik, yang bertujuan untuk terpenuhinya suatu kompetensi dan profesionalisme guru dalam membelajarkan siswa. Pada kurikulum 2013 pendekatan yang digunakan adalah pendekatan saintifik, tidak hanya siswa yang dituntut untuk aktif dan kreatif tetapi guru dituntut untuk lehih kreatif dalam mengembangkan pelajaran. Undang-Undang Sistem Pendidikan Nasional No. 20 Tahun 2003 menyatakan bahwa, "pendidikan adalah usaha sadar dan terencana untuk mewujudkan suasana belajar dan proses pembelajaran agar peserta didik secara aktif mengembangkan potensi dirinya untuk memiliki kekuatan spiritual keagamaan, pengendalian diri, kepribadian, kecerdasan, akhlak mulia, serta keterampilan yang diperlukan dirinya, masyarakat, bangsa dan Negara".

Dalam proses pembelajaran khususnya di sekolah dasar siswa diajarkan beberapa mata pelajaran salah satunya adalah bidang Pendidikan Pancasila dan Kewarganegaraan. Pendidikan Pancasila dan Kewarganegaraan adalah mata pelajaran wajib pada struktur kurikulum 2013. Sejalan dengan pernyataan tersebut, dalam Undang-undang Nomor 20 Tahun 2003 tentang Sistem Pendidikan Nasional dijelaskan bahwa PPKn merupakan bahan kajian yang wajib dimuat 
dalam kurikulum pendidikan dasar dan menengah. Sebagai mata pelajaran wajib PPKn merupakan salah satu mata pelajaran yang diberikan mulai dari SD/MI/SDLB sampai SMP/MTs/SMPLB. Melalui mata pelajaran PPKn, siswa diarahkan untuk dapat menjadi warga Negara Indonesia yang berakhlak mulia, bermartabat, menghargai nilai-nilai kemanusian, memiliki hubungan harmonis antar sesama manusia, meningkatkan kepedulian dan menegakkan hukum dan keadilan secara tegas. Pembelajaran PPKn yang diberikan pada SD Gugus III Kecamatan Kuta Utara menggunakan pembelajaran konvensional. Pembelajaran konvensional pada Kurikulum 2013 untuk semua jenjang dilaksanakan dengan menggunakan pendekatan saintifik. Menurut Chusnul (2018 : 140) "pembelajaran Saintifik merupakan pembelajaran yang terpusat kepada peserta didik, peserta didik dituntut untuk menemukan sendiri materi yang berkaitan dengan mata pelajaran tertentu. Pembelajaran dengan metode saintifik memiliki karakteristik sebagai berikut. (1) Berpusat kepada peserta didik, (2) Melibatkan keterampilan proses sains dalam mengonstruksi konsep, hukum atau prinsip, (3) Melibatkan proses-proses kognitif yang pontensial dalam merangsang perkembangan intelek, khususnya keterampilan berpikir tingkat tinggi peserta didik, (4) Dapat mengembangakn karakter peserta didik, (5) Substansi atau materi pembelajaran berbasis pada fakta atau fenomena yang dapat dijelaskan dengan logika atau penalaran tertentu, bukan sebatas kira-kira, khayalan, legenda, atau dongeng semata, serta berbasis pada konsep, teori, dan fakta empiris yang dapat dipertanggungjawabkan, (6) Tujuan pembelajaran dirumuskan secara sederhana dan jelas, namun sistem penyajiannya tetap menarik".

Berdasarkan observasi yang diperoleh dari kepala sekolah dan guru kelas V di SD Gugus III Kecamatan Kuta Utara dalam pelaksanaan pembelajaran tematik yang memuat mata pelajaran PPKn belum dapat terlaksanakan dengan optimal karena dilihat dari keseharian siswa yang kurang memahami mata pelajaran PPKn. Hal tersebut dikarenakan kegiatan pembelajaran yang kurang menarik dan masih monoton. Sehingga kompetensi yang dimiliki siswa kurang optimal. Tidak dapat dipungkuri bahwa dalam proses belajar mengajar hanya beberapa siswa yang aktif mengikuti pembelajaran, sehingga siswa yang kurang aktif cenderung hanya mendengarkan dan mengalami kejenuhan, masih kurangnya kerja sama antar siswa saat pembelajaran atau memecahkan masalah dalam pembelajaran. Hal ini tentu menjadi masalah bagi tercapainya tujuan pembelajaran. Untuk mengatasi kejenuhan itu perlu diciptakan situasi dan kondisi belajar mengajar yang bervariasi. Kejenuhan siswa dalam memperoleh pelajaran dapat diamati selama proses belajar mengajar berlangsung seperti kurang perhatian, mengantuk, mengobrol dengan sesama temannya, hal tersebut terjadi karena kurang optimalnya penggunaan media pembelajaran. Untuk itu dalam mencermati situasi yang ada dalam pembelajaran hendaknya guru memilih dan menentukan strategi pembelajaran yang tetap agar tujuan pembelajaran dapat tercapai dan siswa dapat berperan aktif dalam proses pembelajaran. Pada proses pembelajaran guru mempunyai peranan penting dalam menentukan keberasilan siswa dalam belajar, khususnya pada muatan materi PPKn.

Dari berbagai model pembelajaran yang digunakan guru, yang bertujuan untuk membenahi kompetensi pengetahuan PPKn. Model pembelajaran yang diterapkan harus dapat membuat siswa aktif dalam pembelajaran dan dapat meningkatkan kualitas belajar mengajar sesuai harapan yang ada dalam kurikulum. Untuk mencapai tujuan pembelajaran harus menggunakan model pembelajaran yang inovatif salah satunya adalah model pembelajaran kooperatif tipe jigsaw. Menurut Kurniasih dan Sani (2016:24) Model pembelajaran jigsaw adalah model pembelajaran kooperatif yang didesain untuk meningkatkan rasa tanggung jawab siswa terhadap pembelajarannya sendiri dan juga pembelajaran orang lain. Dalam model pembelajaran jigsaw ini keaktifan siswa sangat dibutuhkan. Kunci model kooperatif tipe jigsaw ini adalah interdependence setiap siswa terhadap anggota tim yang memberikan informasi yang diperlukan. Artinya para siswa harus memiliki tanggung jawab dan kerja sama yang positif dan saling ketergantungan untuk mendapatkan informasi dan memecahkan masalah yang diberikan. Anggota kelompok bertanggung jawab atas keberasilan kelompoknya dan ketuntasan bagian materi yang dipelajari dan dapat menyampaikan kepada kelompoknya. Penerapan model 
pembelajaran kooperatif tipe jigsaw ini dalam pelaksanaannya dibantu dengan media powerpoint agar pembelajaran yang dilakukan bisa lebih optimal dan bervariasi.

Menurut Arsyad (2013:193) Microsof Powerpoint merupakan salah satu aplikasi yang paling banyak digunakan oleh orang-orang dalam mempresentasikan bahan ajar atau laporan, karya, atau status mereka. Dengan adanya media microsof powerpoint perhatian siswa terfokus dan siswa lebih mudah dalam memahami materi pembelajaran. Upaya peningkatan keaktifan, menciptakan suasana belajar yang menyenangkan dan peningkatan hasil belajar siswa dapat tercapai. Berdasarkan uraian latar belakang diatas, maka dilakukan penelitian eksperimen yang berjudul "Pengaruh Model Pembelajaran Kooperatif Tipe Jigsaw Berbantuan Media Powerpoint Terhadap Kompetensi Pengetahuan PPKn Siswa Kelas V SD Gugus III Kecamatan Kuta Utara Tahun Ajaran 2018/2019".

\section{Metode}

Pelaksanaan penelitian ini diakukan di SD Gugus III Kecamatan Kuta Utara yang terdiri dari delapan sekolah yaitu, SD No. 1 Kerobokan, SD No. 2 Kerobokan, SD No. 3 Kerobokan, SD No. 2 Kerobokan Kaja, SD No. 3 Kerobokan Kaja, dan SD Kalam Kudus. Pelaksanaan penelitian ini dilakukan di kelas V B SD No. 1 Korobokan yang beralamat di jalan Gunung Sangiang Kerobokan sebagai Kekompok Kelas Ekperimen dan Kelas V B SD NO. 2 Kerobokan Kaja yang beralamat di Banjar Muding Kelod Kerobokan sebagai Kelompok Kelas Kontrol yang merupakan sampel dari penelitian.

Rancangan penelitian yang digunakan dalam penelitian ini adalah penelitian kuantitatif dengan desain eksperimen semu Bentuk eksperimen semu yang digunakan adalah Nonequivalen Control Group Desain (Sugiyono, 2017:77).. Dalam desain ini terdapat dua kelompok, yaitu kelompok eksperimen dan kelompok kontrol. Desain tersebut dapat diformulasikan dengan gambar sebagai berikut.

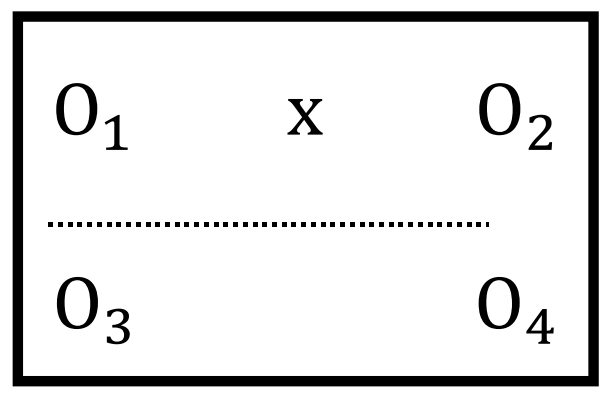

Gambar 1. Rancangan Penelitian Nonequivalent Control Group Desain

\section{Keterangan:}

$\mathrm{O}^{1}=$ Pre-test pada kelompok eksperimen

$\mathrm{O}^{2}=$ Post-test pada kelompok eksperimen

$\mathrm{O}^{3}=$ Pre-test pada kelompok kontrol

$\mathrm{O}^{4}=$ Post-test pada kelompok kontrol

$\mathrm{x}=$ Perlakuan dengan model pembelajaran kooperatif tipe jigsaw berbantuan media powerpoint yang diberikan pada kelompok eksperimen. Sedangkan untuk kelompok kontrol dibelajarkan melalui pendekatan saintifik konvensional).

Penelitian ini dilakukan dengan menempuh tiga tahap yaitu, tahap pertama menentukan gugus yang akan digunakan sebagai tempat penelitian, melakukan penjajagan ke sekolah tujuan yaitu SD Gugus III Keamata Kuta Utara untuk meminta izin melakukan observasi proses pembelajaran, serta mengumpulkan data-data awal yang diperlukan dalam penelitian, melakukan uji kesetaraan populasi dengan menggunakan uji-t, menentukan sampel penelitian yang terdiri 
atas kelas eksperimen dan kelas kontrol, meminta izin kepada kepala SD yang menjadi kelas eksperimen dan kontrol untuk melakukan penelitian di sekolah tersebut dan berkoordinasi dengan guru kelas $\mathrm{V}$ terkait perangkat, instrument dan pelaksanaan pembelajaran.

Menyusun instrument test kompetensi pengetahuan dan merancang perangkat pembelajaran yang terdiri dari RPP, LKS yang mendukung pembelajaran melalui model pembelajaran Kooperatif Tipe Jigsaw berbantuan media powerpoint. Tahap kedua terdiri dari melaksanakan penelitian sebanyak 8 kali pertemuan. Pertemuan pertama memberikan pre-test untuk menyetarakan kedua sampel. Pertemuan ke dua sampai ke 7 untuk memberikan perlakuan pada kelas eksperimen berupan model pembelajaran Kooperatif Tipe Jigsaw berbantuan media powerpoint dan pada kelas kontrol diberikan pembelajaran konvensional. Pertemuan 8 memberikan post-test setelah memberikan perlakuan pada kelompok eksperimen dan kelompok kontrol, analisis data terhadap kompetensi pengetahuan. Dan pada tahap akhir tahap tiga yaitu, menyusun laporan (skripsi) berdasarkan hasil analisis data, melakukan bimbingan dengan kedua dosen, melakukan ujian skripsi sesuai jadwal yang telah ditetapkan dan penggandaan skripsi.

Dalam suatu penelitian untuk menentukan subjek penelitian, langkah awal yang dilakukan adalah menentukan populasi yang akan diteliti populasi merupakan wilayah generalisasi yang terdiri atas objek/subjek yang mempunyai kualitas dan karakteristik tertentu yang ditetapkan oleh peneliti, langkah awal yang dilakukan dalam penelitian ini adalah menentukan populasi yang akan diteliti. Populasi pada penelitian ini adalah seluruh siswa kelas V SD Gugus III Kecamatan Kuta Utara Tahun Ajaran 2018/2019. Berdasarkan populasi yang telah ditentukan selanjutnya diambil perwakilan dari populasi yang mewakili dari seluruh populasi. Perwakilan dari populasi yang mewakili populasi dari seluruh populasi disebut sampel. Dari populasi siswa kelas V SD Gugus III Kecamatan Kuta Utara tahun ajaran 2018/2019, untuk menentukan kelas eksperimen dan kelas kontrol penelitian menggunakan teknik random sampling dengan kelas acak sehingga setiap kelas memiliki peluang yang sama untuk menjadi sampel penelitian. Sampel dalam penelitian ini adalah kelas VB SD No. 1 Kerobokan sebagai kelas eksperimen dan kelas VB SD No. 2 Kerobokan Kaja sebagai kelas kontrol

Dalam penelitian ini, instrument yang digunakan untuk mengukur Penguasaan Kompetensi Pengetahuan PPKn adalah tes. Bentuk tes yang digunakan adalah tes objektif dengan tipe pilihan ganda biasa. Arikunto (2013:179) menyatakan "Tes objektif adalah tes yang dalam pemeriksaannya dapat dilakukan secara objektif". Adapun langkah-langkah yang diterapkan dalam pengkonstruksian tes kemampuan (1) mengidentifikasi standar kompetensi, (2) mengidentifikasi kompetensi dasar, (3) mengidentifikasi dan memaparkan indicator pencapaian siswa, (4) menyusun kisi-kisi tes, (5) menyusun butir-butir tes, (6) uji lapangan, (7) analisis uji lapangan, (8) revisi butir, dan (9) finalisasi instrument. Teknik peskoran dalam tes objektif yang digunakan dalam penelitian ini yaitu:

Setiap butir soal disertai dengan empat alternatif jawaban (a,b, c, d) yang akan dipilih siswa dengan jumlah pertanyaan yaitu 30 butir soal. Setiap intem soal akan diberikan skor (1) bila siswa menjawab benar dan skor (0) bila siswa menjawab salah. Skor dari jawaban siswa akan dijumlahkan dan jumlah tersebut merupakan skor dari penguasaan kompetensi pengetahuan PPKn. Rentang skor penguasaan kompetensi pengetahuan PPKn adalah 0-30. Skor 0 merupakan minimal dan skor 30 merupakan skor maksimal penguasaan kompetensi pengetahuan PPKn. Istrumen dari penelitian ini digunakan untuk mengukur penguasaan kompetensi pengetahuan PPKn siswa pada kedua kelas yang diberikan perlakuan berbeda yaitu kelas yang menggunakan model pembelajaran kooperatif tipe jigsaw dan kelas yang menggunakan pembelajaran konvensional. Tes yang diberikan untuk kedua kelas tersebut pada akhir perlakuanakan digunakan untuk menguji kebenaran hipotesis penelitian.

Dalam penelitian ini data terkumpul akan di analisis menggunakan metode analisis statistik deskriptif dan metode analisis statistic inferensial. Data yang dianalisis merupakan data gain skor yang ternormalisasi dari hasil pre-test dan post-test. Statistic deskriptif digunakan untuk menganalisis data pengetahuan PPKn pada kelompok eksperimen dan kelompok kontrol, statistic deskriptif yang digunakan yaitu mean, standar deviasi dan varians. Statistic inferensial adalah statistic yang digunakan untuk menganalisis data sampel, dan hasilnya akan di generalisasikan ( di inferensiasikan) untuk populasi dimana sampel diambil (Sugiyono 2017:23). Teknik analisis 
data yang dilakukan adalah uji hipotesis menggunakan uji-t, sebelum melakukan uji hipotesis terlebih dahulu dilakukan uji prasyarat analisis data berupa uji normalitas sebaran data dan uji homogenitas varians, apabila data berdistribusi normal dan homogeny maka dilanjutkan dengan analisis statistic parametric dengan teknik uji-t dengan rumus polled varians, dengan criteria pengujian jika harga $t_{\text {hitung }} \leq \mathrm{t}_{\text {tabel }}$, maka $\mathrm{H}_{0}$ diterima, dan jika $\mathrm{t}_{\text {hitung }}>\mathrm{t}_{\text {tabel }}$ maka $\mathrm{H}_{0}$ ditolak . pada taraf signifikan $5 \%$ dengan $\mathrm{dk}=\mathrm{n}_{1}+\mathrm{n}_{2}-2$.

\section{Hasil dan Pembahasan}

Hasil uji hipotesis yang telah diperoleh menunjukan nilai $t_{\text {hitung }}=5.617$, pada taraf dignifikansi $5 \%$ dengan $\mathrm{dk}=61$ diperoleh nilai $t_{\text {tabel }}$ sebesar 2,000. Jika dibandingkan $t_{\text {hitung }}>t_{\text {tabel }}$ maka dari itu hipotesis nol $\left(\mathrm{H}_{0}\right)$ ditolak dan hipotesis alternative $\left(\mathrm{H}_{\mathrm{a}}\right)$ yang menyatakan terdapat perbedaan yang signifikan kompetensi pengetahuan PPKn antara kelompok siswa yang dibelajarkan dengan model pembelajaran Kooperatif Tipe Jigsaw berbantuan media powerpoint dengan kelompok siswa dibelajarkan dengan pembelajaran konvensional ada kelas V SD Gugus III Kecamatan Kuta Utara Tahun Ajaran 2018/2019 diterima.

Perbedaan signifikan kompetensi pengetahuan PPKn antara kelompok siswa yang dibelajarkan dengan model pembelajaran Kooperatif Tipe Jigsaw berbantuan media powerpoint dengan kelompok siswa dibelajarkan dengan pembelajaran konvensional dapat dilihat dari perbedaan hasil analisis statistic deskriptif kedua kelompok tersebut. Secara deskriptif rata-rata gain skor dinormalisasi kompetensi pengetahuan PPKn siswa kelompok eksperimen $\bar{X}=0,218$ lebih dari rata-rata gain skor dinormalisasi kompetensi pengetahuan PPKn kelompok kontrol $\bar{X}$ $=0,129$.

Analisis statistik nilai pretes siswa diperoleh bahwa kedua kelompok kelas setara, setelah diberikan perlakuan berupa penerapan model pembelajaran kooperatif tipe jigsaw berbantuan media powerpoint pada kelas eksperimen diperoleh perbedaan gain skor dinormalisasi kompetensi pengetahuan PPKn siswa. Nilai gain skor dinormalisasi kompetensi pengetahuan PPKn siswa pada kelas eksperimen lebih tinggi dari gain skor dinormalisasi kompetensi pengetahuan PPKn siswa pada kelompok kelas kontrol. Perbedaan tersebut terlihat dari rata-rata gain skor dinormalisasi pengetahuan PPKn siswa yang diberikan perlakuan model pembelajaran kooperatif tipe jigsaw berbantuan media powerpoint lebih tinggi dibandingkan dengan rata-rata gain skor dinormalisasi kompetensi pengetahuan PPKn siswa yang dibelajarkan dengan pembelajaran konvensional.

Pada kelompok eksperimen, kegiatan pembelajaran pada muatan materi PPKn menerapkan model pembelajaran kooperatif tipe jigsaw berbantuan media powerpoint dapat mengaktifkan siswa selama proses pembelajaran berlangsung. Aktifnya proses pembelajaran tersebut dikarenakan penerapan model pembelajaran kooperatif tipe jigsaw berbantuan media powerpoint memberikan sebuah permasalahan dengan berbagai solusi penyelesaian agar siswa mampu untuk menyelesaikan permasalahan sesuai dengan kemampuan yang dimilikinya dan mengembangkan pemahaman siswa dari pada sekedar mengetahuinya. Pemahaman yang diperoleh oleh siswa dapat diaplikasikan kedalam sebuah tugas dengan jangka waktu tertentu yang berkaitan dengan pemahaman, pengaplikasian, penyelidikan, serta penginformasian. Dengan demikian perlakuan model pembelajaran kooperatif tipe jigsaw berbantuan media powerpoint lebih tinggi dibandingkan dengan rata-rata gain skor dinormalisasi kompetensi pengetahuan PPKn siswa yang dibelajarkan dengan pembelajaran konvensional.

Penelitian ini adalah penelitian yang berbentuk quasi eksperimen atau eksperimen semu yang menggunakan rancangan non-equivalent control grop desain yang dianalisis menggunakan uji-t objek penelitian ini adalah kompetensi pengetahuan PPKn kelas V SD Gugus III Kecamatan Kuta Utara Tahun Ajaran 2018/2019. Yang dibelajarkan melalui model pembelajaran kooperatif tipe jigsaw berbantuan media powerpoint dan yang dibelajarkan melalui model pembelajaran konvensional. Pada awal penelitian kelompok eksperimen dan kelompok kontrol diberikan pretest kelompok eksperimen dibelajarkan dengan model pembelajaran kooperatif tipe jigsaw berbantuan media powerpoint dan yang dibelajarkan melalui model pembelajaran konvensional sebanyak 6 kali pertemuan dan pada akhir penelitian kelompok eksperimen dan kelompok 
kontrol diberikan post-test kemudian hasil pre-test dan post-test dari kedua kelompok tersebut akan diolah menjadi nilai gain skor ternormalisasi yang sudah dilakukan memperoleh hasil 0,218 lebih besar dari kelompok kontrol yaitu 0,097. Kemudian rata-rata gain skor ternormalisasikan kompetensi pengetahuan PPKn kelompok eksperimen dan kelompok kontrol dikonversikan pada PAN skala 5, rata-rata kompetensi pengetahuan PPKn eksperimen dan kontrol sama-sama berada pada kategori cukup, hasil rentangan yang diperoleh pada setiap kelompok kelas berada pada kategori cukup dimana hasil rentangan yang diperoleh pada setiap kelompok kelas yang bersangkutan dan tidak dapat dibandingkan dengan kelas lain.

Berdasarkan data gain skor ternormalisasi kompetensi pengetahuan PPKn, yang berdistribudi normal dan varians yang homogeny, diperleh hasil uji-t dengan harga $t_{\text {hitung }}=5,617$ harga ini kemudian dibandingkan dengan tabel pada taraf signifikansi $5 \%$ dengan $\mathrm{dk}=61$, sehingga diperoleh harga $t_{\text {tabel }}=2,000$ oleh karena harga $t_{\text {hitung }} 5,617>2,000 t_{\text {tabel }}$ maka $H_{0}$ ditolak berikut disajikan rekapitulasi hasil analisis data dengan menggunakan uji-t pada tabel1

Tabel 1. Rekapitulasi Analisis Uji-t

\begin{tabular}{|c|c|c|c|c|c|c|c|c|}
\hline NO & Sampel & $\begin{array}{c}\text { Rata- } \\
\text { Rata }\end{array}$ & Varians & $\mathrm{Dk}$ & $\mathrm{N}$ & thitung & tabel & Kesimpulan \\
\hline 1 & $\begin{array}{c}\text { Kelas } \\
\text { Eksperimen }\end{array}$ & 0,218 & 0,024 & 61 & 33 & \multirow{2}{*}{5,617} & 2,000 & $\mathrm{H}_{0}$ Ditolak \\
\cline { 1 - 6 } 2 & $\begin{array}{c}\text { Kelas } \\
\text { Kontrol }\end{array}$ & 0,097 & 0,014 & 61 & 30 & 5 & \\
\hline
\end{tabular}

Hal ini menunjukan hasil penelitian signifikan. Hal ini berarti, terdapat perbedaan yang signfikan kompetensi pengetahuan PPKn antara kelompok siswa yang dibelajarkan dengan model pembelajaran Kooperatif Tipe Jigsaw berbantuan media powerpoint dengan kelompok siswa dibelajarkan dengan pembelajaran konvensional pada kelas V SD Gugus III Kecamatan Kuta Utara Tahun Ajaran 2018/2019. Hail perhitungan dari kedua kelompok yang mulanya memiliki kemampuan yang setara, namun setelah kelompok eksperimen di berikan perlakuan, nilai kompetensi pengetahuan PPKn kelompok eksperimen lebih baik dari kelompok kontrol. Perbedaan kompetensi pengetahuan tersebut disebabkan oleh beberapa faktor yaitu (1) pemberian perlakuan berupan model pembelajaran Kooperatif Tipe Jigsaw pada kelompok eksperimen, dan (2) pemberian perlakuan berupan model pembelajaran Kooperatif Tipe Jigsaw pada kelompok eksperimen berbantuan media powerpoint. Penjelasan mengenai faktor-faktor tersebut sebagai berikut.

Model pembelajaran jigsaw adalah model pembelajaran kooperatif yang didesain untuk meningkatkan rasa tanggung jawab siswa terhadap pembelajarannya sendiri dan juga pembelajaran orang lain". Dalam model pembelajaran jigsaw ini keaktifan siswa sangat dibutuhkan. Kunci model kooperatif tipe jigsaw ini adalah interdependence setiap siswa terhadap anggota tim yang memberikan informasi yang diperlukan. Artinya para siswa harus memiliki tanggung jawab dan kerja sama yang positif dan saling ketergantungan untuk mendapatkan informasi dan memecahkan masalah yang diberikan. Anggota kelompok bertanggung jawab atas keberasilan kelompoknya dan ketuntasan bagian materi yang dipelajari dan dapat menyampaikan kepada kelompoknya. Menurut Kurniasih dan Sani (2016:25) Model pembelajaran Jigsaw memiliki beberapa kelebihan yaitu: (1) mempermudah pekerjaan guru dalam mengajar, karena sudah ada kelompok ahli yang bertugas menjelaskan materi kepada rekan-rekannya, (2) pemerataan penguasaan materi dapat dicapai dalam waktu yang lebih 
singkat, (3) metode pembelajaran ini dapat melatih siswa untuk lebih aktif dalam berbicara dan berpendapat.

Menurut Arsyad (2013:193) Microsof Powerpoint merupakan salah satu aplikasi yang paling banyak digunakan oleh orang-orang dalam mempresentasikan bahan ajar atau laporan, karya, atau status mereka. Dengan adanya media microsof powerpoint perhatian siswa terfokus dan siswa lebih mudah dalam memahami materi pembelajaran.

Menurut Asyhar, (2011:185) "Microsoft Powerpoint merupakan program aplikasi presentasi yang sangat popular dan paling banyak digunakan saat ini untuk berbagai kepentingan presentasi, baik pembelajaran, presentasi produk, meeting, seminar, lokakarya dan sebagainya." Dengan menggunakan powerpoint anda dapat membuat presentasi secara profesional dan jika perlu hasil presentasi anda dapat dengan mudah ditempatkan disever web sebagai halaman web untuk diakses sebagai bahan pembelajaran atau informasi yang lainnya.

Dilihat dari kaidah pembelajaran, meningkatkan kadar hasil belajar yang tinggi, sangat ditunjang oleh penggunaan media pembelajaran. Melalui media potensi indera peserta didik dapat diakomodasi sehingga kadar hasil belajar akan meningkat. Salah satu aspek media yang diunggulkan yang mampu meningkatkan kompetensi pengetahuan adalah bersifat multimedia, yaitu gabungan dari berbagai unsur media seperti teks, gambar, animasi, video. Sesuai dengan penjelasan tersebuat dapat disimpulkan bahwa model pembelajaran kooperatif tipe jigsaw berbantuan media powwerpoint merupakan model pembelajaran kooperatif yang didesain untuk meningkatkan rasa tanggung jawab siswa terhadap pembelajarannya sendiri dan juga pembelajaran orang lain. Dalam penerapannya model pembelajaran kooperatif tipe jigsaw dibantu dengan media powerpoint yang merupakan salah satu aspek media yang diunggulkan yang mampu meningkatkan kompetensi pengetahuan adalah bersifat multimedia, yaitu gabungan dari berbagai unsur media seperti teks, gambar, animasi, video. Model pembelajaran jigsaw adalah model yang digunakan untuk melatih dan mengembangkan keterampilan siswa agar siswa mau mengemukakan pendapat dan saling bekerjasama. Adapun keunggulan model Jigsaw yaitu: (1) mempermudah pekerjaan guru dalam mengajar, karena sudah ada kelompok ahli yang bertugas menjelaskan materi kepada rekan-rekannya, (2) pemerataan penguasaan materi dapat dicapai dalam waktu yang lebih singkat, (3) metode pembelajaran ini dapat melatih siswa untuk lebih aktif dalam berbicara dan berpendapat.

Keunggulan yang dimiliki oleh model pembelajaran Jigsaw akan memberikan pengaruh terhadap proses pembelajaran yang dialami oleh siswa dan akan membantu pemahaman siswa. Sebuah model pembelajaran dapat dipadukan dengan media salah satunya adalah media powerpoint, media powerpoint adalah media pembelajaran yang digunakan oleh guru yang berupa konsep-konsep materi yang disertai dengan gambar dan animasi. Sehingga melalui media powerpoint akan mempermudah siswa didalam memahami materi yang sedang dipelajari. Penerapan model pembelajaran Jigsaw berbantuan media powerpoint dalam proses pembelajaran dengan banyaknya keunggulan yang dimiliki jelas akan dapat mempengaruhi kompetensi pengetahuan siswa termasuk mata pelajaran PPKn. Argument tersebut disampaikan berdasarkan penjelasan secara teoretis pada kajian teori dan juga beberapa penelitian relevan yang sudah dilakukan peneliti lainnya dengan mendapatkan hasil bahwa model pembelajaran Jigsaw berpengaruh terhadap kompetensi pengetahuan siswa. Hasil temuan pada penelitian ini memiliki persamaan dengan penelitian yang dilakukan oleh Susanti (2017) menunjukan bahwa terdapat perbedaan yang signifikan kompetensi pengetahuan IPS siswa yang mengikuti model kooperatif tipe jigsaw dan siswa yang mengikuti pembelajaran konvensional. Hal ini dilihat dari hasil perhitungan menggunakan uji-t yang dilakukan pada taraf signifikansi $5 \%$ dan $\mathrm{dk}=74$ diperoleh thitung $=3,38$ sedangkan ttabel $=2,000$. Dengan demikikan thitung $=3,38>$ ttabel $=2,000$ sehinggan Ho ditolak. Yang berarti terdapat perbedaan yang signifikan kompetensi pengetahuan IPS antara siswa yang dibelajarkan melalui model pembelajaran kooperatif tipe jigsaw dengan siswa yang dibelajarkan dengan pembelajatan konvensioanal pada kelas IV SD Gugus Untung Surapati Denpasar Timur Tahun Ajaran 2016/2017. Kesamaan dengan penelitian ini yaitu dalam penggunaan model pembelajaran kooperatif tipe jigsaw dan perbedaannya pada media, muatan materi tidak PKn dan subjek penelitian. Dan Penelitian yang dilakukan oleh Anggreni (2017) 
menunjukan bahwa terdapat perbedaan yang signifikan kompetensi pengetahuan IPS siswa yang mengikuti model kooperatif tipe jigsaw dan siswa yang mengikuti pembelajaran konvensional. Hal ini dilihat dari hasil analisis diperoleh thitung $=4,91$ dan ttabel $=2,000$ pada taraf signifikansi $5 \%(\alpha=0,05)$ dengan $\mathrm{dk}=\mathrm{n} 1+\mathrm{n} 2-2=32+32-2=62$. Oleh karena thitung $=4,91>\operatorname{ttabel}(\alpha=$ $0,05)=2,000$ maka H0 ditolak dan Ha diterima. Sehingga dapat dikatakan bahwa terdapat perbedaan yang signifikan antara penguasaan kompetensi pengetahuan IPS siswa yang dibelajarkan dengan model kooperatif tipe jigsaw berbantuan media audio visual dan pembelajaran konvensional pada siswa kelasIV SD Gugus 1 Dalung. Kesamaan dengan penelitian ini yaitu dalam penggunaan model pembelajaran kooperatif tipe jigsaw dan perbedaannya pada media, muatan materi tidak PKn dan subjek penelitian.

\section{Simpulan dan Saran}

Berdasarkan hasil penelitian dan pembahasan dari analisis data dapat disimpulkan bahwa nilai gais skor kompetensi pengetahuan PPKn kelompok siswa yang dibelajarkan dengan model pembelajaran kooperatif tipe jigsaw berbantuan media powerpoint dikonversikan pada tabel PAN Skala 5 terdapat siswa kategori 0 sangat tidak baik, 8 siswa kategori tidak baik, 7 siswa kategori cukup baik, 13 siswa kategori baik, dan 5 siswa sangat baik. Untuk gain skor kompetensi pegetahuan PPKn kelompok siswa yang dibelajarkan dengan pembelajaran konvensional dikonversikan juga pada PAN Skala 5 terdapat 0 siswa kategori sangat tidak baik, 6 siswa kategori tidak baik, 6 siswa kategori cukup baik, 11 siswa kategori baik, dan 7 siswa kategori sangat baik.

Hasil uji hipotesis menyatakan bahwa terdapat perbedaan yang signifikan nilai gain skor dinormalisasi dari kedua kelompok kelas. Hal ini dibuktikan dengan analisis uji-t diperoleh $t_{\text {hitung }}$ $=5,617$, pada taraf signifikansi $5 \%$ dengan $\mathrm{dk}=63$ diperoleh nilai $\mathrm{t}_{\text {tabel }}=2,00$. Karena $\mathrm{t}_{\text {hitung }}=5,617$ $>t_{\text {tabel }}=2,00$ maka $\mathrm{H}_{0}$ ditolak dan hipotesis alternatif $\left(\mathrm{H}_{\mathrm{a}}\right)$ yang menyatakan terdapat perbedaan yang sisnifikan kompetensi pengetahuan PPKn antara kelompok siswa yang dibelajarkan melalui model pembelajaran Kooperatif Tipe Jigsaw berbantuan media powerpoint dengan kelompok siswa dibelajarkan secara konvensional pada kelas V SD Gugus III Kecamatan Kuta Utara Tahun Ajaran 2018/2019 diterima. Dari hasil analisis tersebut dapat disimpulkan bahwa model pembelajaran Kooperatif Tipe Jigsaw berbantuan media powerpoint berpengaruh terhadap kompetensi pengetahuan PPKn siswa kelas V SD Gugus III Kecamatan Kuta Utara Tahun Ajaran 2018/2019.

Berdasarkan simpulan dari peneliti, dapat diajukan beberapa saran sebagai tidak lanjut dari penelitian ini. Saran ini diajukan kepada berbagai pihak yang terkait dengan manfaat hasil penelitian. (1) Kepada Guru Berdasarkan temuan peneliti, disarankan kepada guru diharapkan dapat memvariasikan proses pembelajaran yang dilakukan di kelas dengan menerapkan model pembelajaran atau penggunaan media pembelajaran seperti model pembelajaran kooperatif tipe jigsaw berbantuan media powerpoint agar siswa mampu mengembangkan kemampuan dan pemahamannya. (2) Kepada Sekolah Berdasarkan temuan peneliti, disarankan kepada pihak sekolah tempat penelitian diharapkan mampu untuk memanfaatkan hasil penelitian sebagai pendukung sumber belajar guru dalam meningkatkan kualitas pembelajaran dengan menciptakan pembelajaran yang menyenangkan di sekolah sehingga sekolah mampu menghasilkan siswa yang berkualitas. (3) Kepada Peneliti Lain Berdasarkan temuan peneliti, disarankan kepada peneliti agar hasil penelitian ini digunakan sebagai referensi untuk melaksanakan penelitian selanjutnya atau menemukan inovasi kegiatan pembelajaran lainnya yang bermakna dan menyenangkan bagi siswa

\footnotetext{
* Corresponding author. 


\section{Daftar Pustaka}

Agung, A.A Gede. 2014. Buku Ajaran Metodelogi Penelitian Pendidikan.Malang: Aditya Media Publishing.

Arikunto, Suharshimi. 2013. Dasar-Dasar Evaluasi Pendidikan. Jakarta: Bumi Aksara

Asyhar, Rayandra. 2011. Kreatif Mengembangkan Media Pembelajaran. Jakarta: Gaung Persada (GP) Press.

Arsyad, Azhar. 2013. Media Pembelajaran. Jakarta: PT Rajagrafindo Persada.

Chotimah, Chusnul. 2018. Paradigma Baru Sistem Pembelajaran. Yogyakarta: Ar-Ruzz Media.

Dantes, 2017, Desain Eksperimen Dan Analisis Data. Depok: PT RAJA GRAFINDO PERSADA.

Dani Susanti, Ni Luh Putu. 2017. "Pengaruh Model Pembelajaran Kooperatif Tipe Terhadap Penguasaan Kompetensi Pengetahuan IPS Siswa Kelas IV SD”. Ejournal PGSD Universitas Pendidikan Ganesha. Tersedia dalam http://lib.undiksha.ac.id/statistik/media.php?module=Skripsi\&halaman=5 $\underline{85}$ (diakses pada tanggal 1 Februari 2019)

Darmadi, Hamid. 2017. Metode Penelitian dan Sosial.Bandung: Alfabeta.

Dian Krisna Anggreni, Luh Putu. 2017. "Pengaruh Model Pembelajaran Kooperatif Tipe Jigsaw Berbantuan Media Audio Visual Terhadap Penguasaan Kompetensi Pengetahuan IPS Siswa Kelas IV Sd Gugus 1 Dalung Tahun Ajaran 2016/2017". E-journal PGSD Universitas Pendidikan Ganesha. Tersedia dalam https://ejournal.undiksha.ac.id/index.php/JJPGSD/article/download/1098 4/7037 (diakses pada tanggal 1 februari 2019)

Hamalik, Oemar. 2014. Kurikulum dan Pembelajaran. Jakarta: Bumi Aksara.

Koyan, Wayan. 2012. Statistik Pendidikan Teknik Analisi Data Kuantitatif. Singaraja Bali: Universitas Pendidikan Ganesha.

Kosasih, E. 2014.Strategi Pembelajaran Implementasi kuriklum 2013. Bandung: Yrama Widya

Kurniasih, Imas dan Berlin Sani. 2014. Sukses Mengimplementasikan Kurikulum 2013 (Memahami Berbagai Aspek Dalam Kurikulu 2013).Surabaya: Kata Pena.

Setyosari, Punaji.2015.Metode Penelitian Pendidikan \& Pengembangan.Jakarta Prenamedia Grop.

Shoimin, Aris. 2014. 68 Model Pembelajaran Dalam Kurikulum 2013. Yogyakarta: ArRuzz Media

Sudijono, Anas. 2013. Pengantar Evaluasi Pendidikan. Jakarta: PT Raja Grafindo Persada.

Sugiyono. 2017. Statistika Untuk Penelitian. Bandung: ALFABETA

Sugiyono. 2018. Metode Penelitian Kuantitatif Kualitatif dan R\&D. Bandung: Alfabeta. Slavin, Robet E. 2015.Cooperatif Learning Teori Riset dan Praktik. Bandung:

Nusa Medias 